\title{
The Knowledge Enablers of Knowledge Transfer: An Empirical Study in Telecommunications Companies
}

\author{
Khaled Mohammad Al-Gharibeh
}

Ajloun National Private University-Ajloun-Jordan

\begin{abstract}
Recently knowledge sharing (KS) becomes the focus of attention from many practitioners and academics. Knowledge transfer is an integral part of knowledge sharing. In order to build on the knowledge asset, organizations need to share knowledge and transfer this knowledge within organizational networks. Nowadays, managers need to understand which knowledge enablers are effective to provide a conducive environment for KS. Currently, managers need to support and facilitate knowledge transfer process rather than control it. This study focuses on the knowledge transfer by identifying it's enablers as discussed in many previous studies Therefore, the purpose of this study is intended to investigate to identify the knowledge enablers which need to be developed as mechanisms to stimulate knowledge creation, protect knowledge and build effective knowledge sharing behavior in telecommunications companies. The empirical examination of research model indicated that knowledge strategy, organizational culture, information technology, and knowledge leadership as knowledge enablers have a significant positive relationship with knowledge transfer.
\end{abstract}

Keywords: Knowledge Management; Knowledge transfer; Business Managers

\section{Introduction}

In contemporary economy, knowledge includes knowing about people, money, leverage, learning, flexibility, power and competitive advantage. Drucker (1993) wrote that "Knowledge has become the key economic resource and the dominant and perhaps even the only-source of competitive advantage". In this said two concepts -knowledge as an economic resource and knowledge as a source of competitive advantage -- made significant impact on the traditional management approach and demanded a paradigm shift. Knowledge is more relevant to sustain business than capital labor or land. Nevertheless, it remains the most neglected asset. It is more than justified that true believe and essential for action, performance and adoption, knowledge provides the ability to respond to novel situation. Most organizations realized that knowledge is a source of competitive advantage and a primary factors in knowledge- based economy .In other words, it is to deal astutely with knowledge, which has been stressed by Drucker (1993), Nonaka and Takeuchi (1995). According to Nonaka and Takeuchi's (1995) understanding, we should consider knowledge transfer as a transfer of tacit or explicit knowledge in interaction between individuals. On the other hand, explicit knowledge is cognitive that can be expressed in formal speech and exchanged in the form of data. Whereas tacit knowledge includes

Copyright (C) 2011 Khaled Mohammad. This is an open access article distributed under the Creative Commons Attribution License unported 3.0, which permits unrestricted use, distribution, and reproduction in any medium, provided that original work is properly cited. Contact author: Khaled Mohammad, e-mail: Khaledalgaribeh@yahoo.com 
individual, context related, analogous and practical related knowledge, tacit knowledge can only be transferred in face to face situation. Knowledge transfer linked knowledge to human interaction that is embedded in organizational contexts Wilkesmann et al (2007). O' Dell Grayson (1998) states that knowledge transfer enablers include Technology, culture, leadership, and measurement. Davenport and Prusak (2000) suggested that knowledge transfer process involves two actions: transmission of knowledge to potential recipient and knowledge absorption by that recipient that could eventually lead to changes in behavior or the development of new knowledge. Also, Davenport and Prusak (1998) identify four knowledge processes in a centralized $\mathrm{KM}$ approach. They are; i) knowledge generation (knowledge creation and knowledge acquisition); ii), knowledge codification (storing); iii), knowledge transfer (sharing); iv) and knowledge application. Nowadays, Knowledge transfer is considered the nerve of the knowledge management process within organization.

Many organizations begin research about supporting knowledge transfer rather than controlling it. Many organizations begin their knowledge management efforts by trying to understand what, where support knowledge transfer and how support to knowledge transfer. In supporting KT behavior in organization, the management must develop a mechanism which can support the conducive environment for knowledge transfer. Therefore, this study is aimed at identifying the concepts of knowledge enablers which are assumed to support knowledge transfer behavior.

\section{Objective Research}

The overall aim of this study is investigate the effects of knowledge enablers (organizational culture, information Technology, knowledge strategy and knowledge leadership) on knowledge transfer. To achieve this, there is a need to identify the enablers that affect on knowledge transfer process within Zain Company in Kuwait. Some researchers believed that it is important to effectively and efficiently manage these organizational elements (knowledge enablers) in order to have a successful knowledge management process Monavvarian, A., and Kasaei, M (2007). This paper attempts to verify the effects of these elements on one aspect of the KM process (i.e. knowledge transfer as a part from sharing of knowledge management process). Knowledge transfer is a dynamic process to exchange knowledge between a group or individuals to work with others.

\section{Literature Review}

This paper focuses on the knowledge transfer by identifying it's enablers it as discussed many previous studies as following:

Von Krogh, et al (2000) list five enablers for strategy and knowledge creation: instill a Knowledge Vision, Manage Conversations, and Mobilize Knowledge Activists, Create the Right Context and Globalize Local Knowledge. They argue that managers need to support knowledge creation rather than Control it. They explain knowledge enabler's as following: that knowledge vision is encouraged to create new knowledge and determined mission, Manage conversation which helps to share tacit knowledge process. They believe that "good conversations are the cradle of social knowledge in any organization (...), they allow the first and most essential step of knowledge creation: sharing tacit knowledge within amicrocommunity". Knowledge Activists are persons who facilitate the knowledge creation process, create right context and globalize local knowledge aiming at transferring locally created knowledge throughout perhaps globally distributed company. They argue also that shared context is such a place that can be "physical, virtual, mental, or- more likely- all three" (2000, P 7). They said that knowledge enabling effect is support not control. 
Lee and Choi (2003) looked at three major factors for managing knowledge: enablers, processes, and organizational performance. Enablers are influencing factors that help foster knowledge consistently through the firm by stimulating knowledge creation, protecting knowledge, and facilitating the sharing of knowledge. Knowledge processes are knowledge management activities that help create a coordination structure that manages knowledge effectively. They divide the enablers into seven enablers: (1) collaboration - degree of active support and help in an organization; (2) trust - degree of reciprocal faith in others" intentions, behaviors, and skills toward organizational goals; (3) learning - degree of opportunity, variety, satisfaction, and encouragement for learning and development in an organization; (4) centralization - degree of authority and control over decisions; (5) formalization degree of formal rules, procedures, and standard polices; (6) T-shaped skills - degree of understanding of his or her own and other's task areas; and (7) information technology support - degree of IT support for collative work, for communication, for searching and accessing, for simulation and prediction, and for systematic storing. They found that collaboration; trust, learning, and centralization are significant (.05 significance level) predictors for knowledge creation. Collaboration is positively related with socialization, externalization, and internalization and not related to combination. Trust is related to all knowledge creation modes. Learning is related to socialization and internalization. Centralization is negatively related to socialization, externalization, and internalization while not related to combination. Formalization and T-shaped skills of members are not related to knowledge creation. IT support is significantly related to knowledge combination only. Then knowledge creation is positively related to organizational creativity, which is positively related to organizational performance.
Aurum et al., (2007) divide the knowledge management enablers into four enablers, leadership, technology, culture and measurement. They considered leadership and technology to be the most significant as top-down KM strategies and mechanism knowledge management. They argue that leadership evaluates the role of leadership in managing knowledge within the organization. Culture is concerned with the climate of the knowledge sharing environment, as well as the culture in the organization that promotes the knowledge sharing. Technology examines the technology aspect of KM practice. Measurement aims to find out if there are effective measures to indicate the success or failure of KM practice in organization.

A study by Von krogh et al , (1997) on "knowledge activists " defined knowledge activists as someone, some groups or departments that take on a particular responsibility for energizing and coordinating knowledge creation efforts throughout the corporation. The study aimed at explaining the role of knowledge activists in the knowledge creation company as: catalysts of knowledge creation, connectors of knowledge creation initiatives and merchants of foresight. They note that activism help to reduce the time and cost that are needed for knowledge creation process, in addition to its enabler.

Nonaka and Toyama (2005) presented a typology of organizational knowledge based on the interaction between subjectivity, objectivity and synthesis. They focused on seven bases of knowledge creation that consisted of the following: knowledge vision, driving objective, which gives direction and energy to the SECL process, the SECL process dialogues and practice, (ba) an existential place for the SECL process, knowledge assets, which are inputs and outputs of the SECL process and environment as an ecosystem of knowledge. Also Knowledge is created through the synthesis of thinking and actions 
of individuals. They said that the theory of knowledge creation is based on an idealistic pragmatism which synthesizes the rational pursuit of appropriate ends. They gave the main role for the leadership on knowledge vision and ba. This study is an attempted to establish the theory of knowledge-creating firms to explain the complex process of knowledge being created organizationally.

Al- Taher (2007) in a thesis entitled "innovation and knowledge transfer in Jordan pharmaceutical industry" tried to develop and test a model of the determinants of knowledge transfer and innovation in Jordanian pharmaceutical industry. The study had shown significant relationships between knowledge transfer and innovation. Also, there is a positive relationship between reflection and knowledge transfer, there is a positive retaliation between dialogue and knowledge transfer and there is a positive relationship between double loop learning and knowledge transfer.

Von Krogh et al .,(2000) list five enablers for strategy and knowledge creation: instill a Knowledge Vision, Manage Conversations, and Mobilize Knowledge Activists, Create the Right Context and Globalize Local Knowledge. They argue that managers need to support knowledge creation rather than Control it. They explain enabler's knowledge as following: that knowledge vision is encouraged to create new knowledge and determined mission, Manage conversation which helps to share tacit knowledge process. They believe that "good conversations are the cradle of social knowledge in any organization (...), they examined the first and most essential step of knowledge creation: sharing tacit knowledge within amicrocommunity" Knowledge Activists are persons that facilitate the knowledge creation process, also the right context and globalized local knowledge help knowledge creation process . They argue also that shared context is such a place which can be "physical, virtual, mental, or- more likelyall three" (2000, P7).

Finally, defined Knowledge enablers are organization mechanism that is done consistently and consciously to develop knowledge within organization, Ichijo, K., G et al (1998), Grotenhuis, F.D.J. and M.P. Weggeman (2002). Several researchers are considered as precondition from knowledge process Choi, B (2002). Whereas, some researchers defined knowledge Enablers as influencing factors that help foster knowledge consistently through the firm by stimulating knowledge creation, protecting knowledge, and facilitating the sharing of knowledge Lee and Choi (2003). Based on the literary review and the result of studies in Knowledge enablers area we can define knowledge enablers as organization elements that help foster knowledge transfer consistently within organization.

Table 1 shows the components of knowledge enablers mentioned here based on several views of researchers. Based on table (1): 
Table 1: Components of Knowledge Enablers are Mentioned Here Based on Several Views of Researchers

\begin{tabular}{|l|l|}
\hline Authors & Knowledge enabler \\
\hline Von krogh et al , (1997) & knowledge activists \\
\hline Pan and Scarborough (1998) & Culture, Structure, Technology \\
\hline Von Krogh, et al (2000) & $\begin{array}{l}\text { Knowledge Vision, Manage Conversations, and } \\
\text { Mobilize Knowledge Activists, Create the Right } \\
\text { Context and Globalize Local Knowledge }\end{array}$ \\
\hline Alavi and Leidner (2001) & Culture, Organizational, Incentive IT \\
\hline Gold et.al. (2001) & Culture, Structure, Technology \\
\hline Lin et al. (2002) & $\begin{array}{l}\text { Cultural, Organizational, Technological, } \\
\text { Human Resources }\end{array}$ \\
\hline Choi (2002) & \begin{tabular}{l} 
Culture, Structure, People, IT \\
\hline Lee and Choi (2003)
\end{tabular} \\
$\begin{array}{l}\text { Collaboration, trust, learning, centralization, T- } \\
\text { shaped skills, formalization, information } \\
\text { technology }\end{array}$ \\
\hline Smith and McKeen (2003) & $\begin{array}{l}\text { Social, Organizational, } \\
\text { Technological }\end{array}$ \\
\hline Strohmaier (2003) & Organizational, Technological System, People \\
\hline Muller et.al. (2005) & Culture, Incentive \\
\hline Kim and Lee (2006) & $\begin{array}{l}\text { Organizational Culture, Organizational } \\
\text { Structure, IT }\end{array}$ \\
\hline Hilmi Aulawi et al., (2009) & \begin{tabular}{l} 
Culture, Structure, People, IT \\
\hline
\end{tabular} \\
\hline
\end{tabular}

\section{Knowledge Management Enablers}

Based on the above mentioned conclusion, the researcher assumes that knowledge transfer is affected by many enablers. The researcher believes that enablers above mentioned are the most important support knowledge transfer. The suggested research scheme (Figure1) will be utilized to explore the relationship between knowledge enablers and knowledge transfer. Although there is a lack of academic research to support it, there is a relationship between knowledge enablers and knowledge transfer. This study attempts to provide some viewpoints, and empirical results to identify this relationship. In this research, the researcher will suggest many enablers to support knowledge transfer.

The model combines between the knowledge enablers as independent variables, and the knowledge transfer proposed on the dependent variable. In this study, the researcher divides enablers into four categories: organizational culture, information Technology, knowledge strategy and knowledge leadership following is a brief illustration of these enablers:

\section{Organizational Culture}

According to Wen-bao (2007) organizational culture is the common belief, conduct rules and values shared by all organizational members. Organizational culture is classified into three types: (1) Bureaucratic culture: means that most of the work in an organization is standardized and operates on the basis of control and power. Tasks are completed in proper sequence and enterprise ethic is specially emphasized. (2) Innovative culture: means that the work in an organization is challenging and innovative; organizational members are encouraged for adventure and initiative. (3) Supportive 
culture: means an open and harmonious working environment. Participation, teamwork and interpersonal relationship are specially emphasized. Jennex and Olfman (2004) state "An organizational culture that support learning and the sharing and use of knowledge" cultures are altruism, reciprocity, trust, repute, openness, solidarity, sociability, motivation, commitment, and others.

Organizational culture is a system shared by all organizational members that distinguishes the organization from other organizations. Therefore, we can say that organizational culture is a common value and believe customs and rules shared by a certain organization members.

\section{Information Technology}

According to Hein (2004), Brink (2003) and others, technology support refers to knowledge sharing by enabling the communication, collaboration provision of knowledge storing the accumulated knowledge and retrieve knowledge. Ahmad, et al (2009) found that information technology may serve as a cost effective and fast medium to acquire, store, share and transfer knowledge but it needs human's motive and willingness to engage in KM. Some researchers believes that IT Plays four different roles in knowledge management: 1obtaining knowledge, 2- define, store, index, categories, 3- seek identify related content, 4- flexibly express the content based on the various utilization background (Safa, M et al 2006), Cavana, R.et al(2001), Zack(1999). The example of IT facilities support is by providing groupware, online databases, intranet and virtual communities Lin, F.H., (2007). Therefore, Information technology plays a role in leveraging knowledge in the company and helps to create new knowledge. Also IT includes data processing, content management, communication technologies, system and storage.

\section{Knowledge Leadership}

According to Nonaka and Toyama (2005) leadership is a vital knowledge creating which requires active commitment from all the members of the organization, not just from a few elites. Also, Vitala, R (2004) defined some dimensions of knowledge leadership as orienteering of learning, creating climate that supports learning, supporting individual and group level learning process and acting as a role model. Leadership links the context (ba) and the process (SECI). Nonaka et al.,(2000). Leadership plays various roles in knowledge creating process such as: providing vision; creating, energizing and connecting ba; and enabling and promoting the continuous spiral of knowledge creation. Von Krogh et al (2000) said that "managers in the knowledge economy will be figuring out what their company ought to know for the future". Also, we can say that knowledge leadership is an important enabler that helps knowledge transfer and enhances the partially knowledge creation in the company.

\section{Knowledge Strategy}

Strategies such as knowledge transfer strategy, knowledge creation strategy and customer focus strategy are some of the strategies which organizations consider as KM adopting strategies Wiig, K. M (1997), Manasco, B. (1996). The strategy is associated with objectives, goals, the range of business that the company intends to pursue, plans, policies, decisions making and the kind of organization the company is oriented to be and related to in this respect, finely, the nature of contribution that the company intends to make to its shareholders, employees, customers and communities (Andrews, 1980).

\section{Knowledge Transfer}

Knowledge transfer requires the willingness of a group or an individual to work with 
others, and share knowledge to their mutual benefit. Dixon's (2000) defends the following five knowledge transfer mechanisms for sharing knowledge in the organization which are: serial, explicit, tacit, strategic and expert transfer, while Szulanski (1996) defines KT as "dynamic exchanges of knowledge between a source and, a recipient in which the identity of the recipient matters".

\section{Theoretical Framework}

Figure 1 shows that the independent variables in this study are four organizational elements (Knowledge strategy, organizational culture, information technology and knowledge leadership) termed as enablers which provide mechanism for the knowledge transfer in an organization.

$$
\begin{aligned}
& \text { Knowledge strategy } \\
& \text { Organizational culture } \\
& \text { Information technology } \\
& \text { Knowledge leadership }
\end{aligned}
$$

Knowledge transfer

\section{Figure 1: Proposed Model}

The objective of this study is to test the following hypothesis:

- H1: There exists a significant relationship between Knowledge strategy and knowledge Transfer.

- H2: There exists a significant relationship between organizational culture and knowledge Transfer.

- H3: There exists a significant relationship between information technology and knowledge Transfer.

- H4: There exists a significant relationship between knowledge leadership and Knowledge Transfer.

\section{Research Methodology}

This research is a cross-sectional that uses a case study approach and its main purpose is to verify the role of organizational elements such as Knowledge strategy, organizational culture, information technology and knowledge leadership on knowledge Transfer in Zain Company. For the purpose of data collection, the permission was obtained from the administration office. Latest statistics on number of staff for each department were gathered from the head of each unit in every department. Researcher then obtained permission and cooperation of the head of each unit to identify respondent and eventually distribute the questionnaires to the respondents. Survey-based methods were used to collect information on academic staff's opinion about his/her organization's leadership, culture, strategy, information technology facility and knowledge Transfer.

The Questionnaires were sent to 168 employees working in company. Only (127) were returned. The overall response rate for this study was $84 \%$. This is regarded as relatively high, since the respondents are managers and they are supposed to be too busy to answer Questionnaire. A Questionnaire was sent to respondents who are managers, department heads and Assistant managers currently working in the company.

\section{Questionnaire Design}

A five point Likert scale was used to measure how strongly respondents agree or disagree with the statements. Questionnaires on KM 
enablers was adapted and modified from, Safa, M.S et al (2006) Ming, F.L., and Gwo, G. L(2007) Von Krogh et al (2000), Nonaka et al (2000a), Nonaka and Toyama (2005).
Questionnaires on knowledge Transfer were adapted and modified from wilkesmann et al (2007), Ngoc, bich (2005) as shown in table 2.

\section{Table 2: Instrument Construction}

\begin{tabular}{|c|c|c|c|}
\hline \multicolumn{4}{|c|}{ Part A: KM enablers } \\
\hline Section & Construct & Item no. & \\
\hline Section 1 & $\begin{array}{l}\text { organizational } \\
\text { culture }\end{array}$ & $1-10$ & \\
\hline Section 2 & $\begin{array}{l}\text { information } \\
\text { technology }\end{array}$ & $11-18$ & \\
\hline Section 3 & Knowledge strategy & $19-26$ & \\
\hline Section 4 & $\begin{array}{l}\text { knowledge } \\
\text { leadership }\end{array}$ & $27-30$ & \\
\hline \multicolumn{4}{|c|}{ Part B: Knowledge transfer } \\
\hline & & $31-39$ & $\begin{array}{l}\text { transfer knowledge } \\
\text { within organization }\end{array}$ \\
\hline \multicolumn{4}{|c|}{ Part C : Demographic Profile } \\
\hline & & \multicolumn{2}{|c|}{$\begin{array}{l}\text { age } \\
\text { gender } \\
\text { working experience } \\
\text { working position } \\
\text { academic qualifications }\end{array}$} \\
\hline
\end{tabular}

\section{Reliability Test}

Reliability test was performed to measure the consistency of respondents' answers to all the items in the questionnaire. The Cronbach's Alpha reliability coefficient of the knowledge Transfer was 0.787 and independent variables were: strategic leadership (0.861); organizational culture (0.972); information technology (0.877); and human resource activities (0.914).

The result indicates that the Cronbach's Alpha for all the variables ranged from 0.70 to 0.80 . In general, reliabilities of less than 0.60 are considered to be poor, those in the 0.7 0range are acceptable, and those over 0.80 are good Cavana, R, Y. et al (2001). Since all the Cronbach"s Alpha values are over the critical point of 0.7 . It shows that the survey's reliability is accepted.

\section{Data Collection Method}

Questionnaires were personally administered by the researcher with the help of some employees of each company. Latest statistics on number of staff for each company were gathered from the employees of each company in every department. Researcher then obtained permission and cooperation of the employees of each company to identify respondent and eventually distribute the Questionnaires to the respondents.

The Questionnaires were sent to 168 employees working in the company. Only (127) were returned. The overall response rate for this study was $84 \%$. This is regarded as relatively high, since the respondents are managers and they are supposed to be too busy to answer Questionnaire. A Questionnaire was sent to respondents who 
are managers, department heads and Assistant managers currently working in the companies.

\section{Correlation and Regression Analyses}

Table 3 summarizes the Pearson correlation between KM enablers and knowledge transfer. The critical value of 0.205 was obtained from the Pearson correlation table at 92 degrees of freedom at the 0.05 level of significance for a two tailed test. From the results, it is shown that the correlations obtained are greater than the critical value. Therefore, there are statistically significant relationship between $\mathrm{KM}$ enablers and knowledge transfer. The value of $r$ between 0.7 and 0.8 indicates a strong relationship between KM enablers and knowledge transfer. Therefore, it can be concluded that there is a positive and significant relationship between organizational culture, information technology, knowledge strategy facility and knowledge leadership and knowledge transfer in the company.

Table 3: Pearson Correlation Results

\begin{tabular}{|lc|}
\hline Knowledge enablers & knowledge transfer(r ) \\
& \\
\hline Organizational culture & 0.723 \\
Information technology & 0.773 \\
Knowledge strategy & 0.757 \\
Knowledge leadership & 0.712 \\
\hline
\end{tabular}

$r(92)=0.205, p>0.05$

Furthermore, the results of the multiple regression analysis and their interpretation are discussed below.

Table 4: Regression Statistics Model Summery

\begin{tabular}{|l|l|l|l|l|}
\hline Model & $\mathrm{R}$ & Rsquare & $\begin{array}{l}\text { Adjusted } \\
\text { Rsquare }\end{array}$ & $\begin{array}{l}\text { Std. Error of } \\
\text { the Estimate }\end{array}$ \\
\hline 1 & .803 & .701 & .666 & .30277 \\
\hline
\end{tabular}

Predictors: (Constant), o CULUTER, INFOTECH, KNOSTRATEGY, KNOLEAD

Table 5: Analysis of Variance for Significance of Independent Variables ANOVA

\begin{tabular}{|l|l|l|l|l|l|}
\hline Model & $\begin{array}{l}\text { Sum of } \\
\text { squares }\end{array}$ & df & $\begin{array}{l}\text { Mean } \\
\text { square }\end{array}$ & F & Sig. \\
\hline Regression & 20.060 & 3 & 5.025 & 50.32 & .000 \\
$\begin{array}{l}\text { Residual } \\
\text { Total }\end{array}$ & $\begin{array}{l}8.023 \\
28.093\end{array}$ & 81 & .100 & & \\
\hline
\end{tabular}

a. Predictors: (Constant), o CULUTER, INFOTECH, KNOSTRATEGY, KNOLEADER

b. Dependent Variable: Knowledge Transfer 
Table 6: Standardised and Unstandardised Coefficients for Independent Variable Coefficients

\begin{tabular}{|l|l|l|l|l|l|}
\hline \multirow{2}{*}{ Model } & \multicolumn{2}{|l|}{$\begin{array}{l}\text { Unstandardized } \\
\text { Coefficients }\end{array}$} & $\begin{array}{l}\text { Unstandardized } \\
\text { Coefficients }\end{array}$ & \multirow{2}{*}{$\mathrm{t}$} & \multirow{2}{*}{ Sig. } \\
\cline { 2 - 4 } & $\mathrm{B}$ & Std.Error & Beta & & \\
\hline (Constant) & .420 & .218 & & 2.022 & .038 \\
O CULUTER & .111 & .091 & .102 & 4.011 & .028 \\
INFOTECH & .149 & .065 & .203 & 2.271 & .025 \\
KNOSTRATEGY & -.028 & .099 & -.026 & -.285 & .776 \\
KNOLEADER & -.091 & .123 & -.082 & -.735 & .464 \\
\hline
\end{tabular}

a. Dependent Variable: KTRANS

The regression result in Table 4 and Table 5 above indicates that 70 percent of the variance $(\mathrm{R}$-square $=0.70)$ in knowledge transfer has been significantly explained by the four independent variables $(\mathrm{F}(3,81)=$ 50.32, $\mathrm{p}<0.05$ ) Thus, this hypothesis is substantiated. The next table, table 6 shows that the variables of information technology $(\mathrm{t}=2.271, \mathrm{p}<0.05)$ and organizational culture $(\mathrm{t}=4.011, \mathrm{p}<0.05)$ are significant predictors of knowledge transfer. The mathematical formula of the aforementioned data is as follow: Knowledge transfer $=0.420$ +0.149 (information technology) + 0.111 (organizational culture).

\section{Conclusion}

Based on the findings, we can say that there is a positive effect of knowledge enablers on knowledge transfer in Zain Company. The verified hypothesis is that knowledge enablers as organizational culture enabler and information technology supported knowledge transfer, while knowledge enablers as knowledge strategy and knowledge leadership did not support knowledge transfer. On the other hand, the organizational culture enabler proved to be the most important enabler for knowledge transfer; followed by information technology. Previous study as Lee and Choi (2003), Lin, LU et al (2006), Kim, S and H, Lee (2006), Goh, S C (2002) found that teamwork and collaboration are important culture to support knowledge sharing in an organization which considers knowledge transfer as a part from knowledge sharing.
Study by O' Dell Grayson (1998) states that knowledge transfer enablers include culture. Therefore, the study found that knowledge transfer is supported by organizational culture enabler. Furthermore, the information technology is also an important enabler that supports knowledge transfer. The results of data analysis indicate that information technology facilitate process of knowledge transfer. A study by 0' Dell Grayson (1998) states that, knowledge transfer enablers include Technology.

Finally, this study found that knowledge transfer needs to be supported by organizational culture and information technology enablers. Future research should take many enablers toward the knowledge management process as knowledge creation, knowledge sharing, knowledge acquisition and knowledge application.

\section{References}

Ahmed, H., Jalil, J. \& Rus, A. M. (2009). The Effect of Knowledge Enablers to Knowledge Acquisition: Evidence: from higher education in Malaysia

Alavi, M. \& Leidner, D.E. (2001). "Review: Knowledge Management and Knowledge Management Systems:Conceptual Foundations and Research Issues," MIS Quarterly, 25(1). 107-36.

AL- Taher, A. (2008). Innovation and Knowledge Transfer in Jordan Pharmaceutical Industry, The Arab Academy 
for Banking and Financial Sciences Faculty of Information Systems and Technology.

Andrew, K.. (1980) .The Concept of Corporate Strategy, 2nd Edition, Dow-Jones Irwin, Homewood, IL.

Aulawi, H., Sudirman, I ,, Sudirman, I., Suryadi, K. \& Govindarajn, R (2009). "Literature Review Towards Knowledge Enablers Which Is Assumed Significantly Influences Ks Behavior," Journal of Applied Sciences Research, 5(12). 2262-2270,

Brink, p. (2003). Social Organizational and Technological Condition that Enable Knowledge Sharing, A thesis presented to faculty of technology, policy and management at the Delft University of technology.

Cavana, R.Y., Delahaye, B.L. \& Sekaran, U. (2001). "Applied Business Research: Qualitative and Quantitative Methods," John Wiley: Australia,.

Choi, B. (2002). Knolwledge Management Enablers, Processes, and Organization Performance: An Integration and Empirical Examination, PhD Thesis, Division of Management Engineering, Korea Advanced Institute of Science of Technology.

Davenport, T. H. \& Prusak, L. (1998). Working Knowledge: How Organization Manage What They Know. Harvard Business School Press: Boston. MA, 1998.

Dixon, N. M. (2000). Common Knowledge. Boston, MA: Harvard business, E-book

Drucker, P. (1993). Post-Capitalist Society. New York. Harper Business Dynamics.

Goh, S. C. (2002). "Managing Effective Knowledge Transfer: An Integrative Framework and Some Practice Implications," Journal of Knowledge Management, 6(1). 2330.
Gold, A. H., Malhotra, A. \& Segars, A. H. (2001). "Knowledge Management: An Organizational Capabilities Perspective," Journal of Management Information Systems, 18(1). 185-214.

Grotenhuis, F. D. J. \& Weggeman, M. P. (2002). Knowledge Management in International Mergers, Knowledge and Process Management, 9(2). 83-89.

Hein, E. (2004). 'Knowledge Sharing on Tap,' Inside knowledge magazine. 7(9). [Online] [Retrieved ganuary2, 2008], Http://www.Ik.Magazine.com.

Jennex, M. \& Olfman, L. (2005). "Assessing Knowledge management Success," International Journal of Knowledge Management, 1(2). 33-49.

Kim, S. \& Lee, H. (2006). "The Impact of Organizational Context and Information Technology on Employee Knowledge Sharing Capabilities," Public Administration Review, 66(3): 370-385.

Lai, M. F. \& Lee, G. G. (2007). "Relationships of Organizational Culture toward Knowledge Activities", Business Process Management Journal, (13:2). .306-322.

Lee, H. \& Choi, B. (2003). "Knowledge Management Enablers, Pr o c e s se $s$, and Organizational Performance: An Integrative View and Empirical Examination", Journal of Management Information System, 20: 179228.

Lin, C., Hung, H.C., Wu, J.Y. \& Lin, B. (2002). "A Knowledge Management Architecture in Collaborative Supply Chain", Journal of Computer Information Systems, 42(5): 83-94.

Lin, H. F. (2007). "Knowledge Sharing and Firm Innovation Capability: An Empirical Study", International Journal of Manpower, 28 (3/4). 315-332. 
Lu,L., Leung, K. \& Koch, P. T. (2006). "Managerial Knowledge Sharing: The Role of Individual, Interpersonal, and Organizational Factors," Management and Organization Review,2(1): 15-41

Monavvarian, A. \& Kasaei, M. (2007). “A KM Model for Public Administration: the Case of Labour Ministry," VINE, The Journal of Information and Knowledge Management System, (37:3). 348-367.

Muller, R. M., Spiliopoulou, M. \& H.J. Lenz . (2005). "The Influence of Incentives and Culture on Knowledge Sharing," In the Proceedings of the 38th Annual Hawaii International Conference on System Science, 3-6 January 2005, Manoa, 247b.

Ngoc, P. T. B. (2005). "An Empirical Study of Knowledge Transfer within Vietnam's IT Companies,". Working paper: Hanoi, Switzerland.

Nonaka, I. (1991). 'The Knowledge Creating Company,' Harvard Business Review, November- December, 96-104.

Nonaka, I \& konno, N. (1998). 'The Concept of $\mathrm{Ba}$ Building Foundation for Knowledge Creation,' California Management Review, 40(3). 40-54.

Nonaka, I. \& Takeuchi, H. (1995). 'The Knowledge Creating Company,' Oxford University press, New York.

Nonaka, I \& Toyama, R. (2005). "The Theory of the Knowledge Creation Firm: Subjectivity, Objectivity and Synthesis," Industrial and corporate change," 14(3). 419-436.

Nonaka, I., Toyama, R. \& Byosiere, P. (2003). 'A Theory of Organizational Knowledge Creation: Understanding the Dynamic Process of Creating Knowledge,'

Nonaka, I., Toyama, R. \& Konno, N. (2000). "SECI, Ba and Leadership: A Unified Model of Dynamic Knowledge Creation", Long Range Planning (32). 5-34.
Nonaka, I, Toyama, R. \& Nagata, A. (2000). "A Firm As A Knowledge-Creating entity: A New Perspective on the Theory of the Firm", Industrial and corporate change 9, 1-20. [Online] [Retrieved ganuary12, 2009],

O’Dell, C. \& Grayson, C. J. (1998). "If only we knew what we know: Identification and transfer of internal best practices," California Management Review, spring, vol. 40, no. 3, 154-174.

Pan, S. L. \& Scarbrough, H. (1998). "A SocioTechnical View of Knowledge-Sharing at Buckman Laboratories," Journal of Knowledge Management, 2(1). 55-66.

Safa, M. S., Shakir, F. \& Boon, 0. K. (2006)."Knowledge Management: Practice and Performance of NGO in Maldives", International Journal of Management \& Entrepreneurship, (2:1). 69-86.

Szulanski, G. (1996). "Exploring Internal Stickiness; Impediments to the Transfer of Best Practice within the Firm", Strategic Management Journal, 27- 44.

Viitala, R. (2004). "Towards Knowledge Leadership", Leadership \& Organization Development Journal, (25:6).528-544.

Von Krogh, G. (1998)." Care in Knowledge Creation", California Management Review, 1 (40). 133-153.

Von Krogh, G., Ichijo, K. \& Nonaka, I. (2000). Enabling Knowledge Creation. How to Unlock the Mystery of Tacit Knowledge and Release the Power of Innovation, Oxford Press.

Von Krogh, G., Nonaka, I. \& Icijo, k. (1997). "Develop Knowledge Activists," European Management Journal 15 (5) .

Wen-bao, Lin. (2007). 'The Effect of Knowledge Sharing Model Expert System with Application,' 134 (2). 508- 1521.

Wiig, K. M. (1997). "Knowledge Management: Where Did It Come from and Where Will It 
Go?," Expert Systems with Applications, 13(1). 1-14.

Wilkesmann, U., Wilkesmann, M. \& Virgillito, A. (2007). "Requirements for Knowledge Transfer in Hospital: How Can Knowledge Transfer be Supported in Hospitals?," discussion papers des zentrums fur weiterbildung universitat Dortmund, ISSN: 1863 - 0294.

Zack, M. H. (1999). Knowledge and Strategy. Butterworth Heinemann: Boston, MA, 1999. 